\title{
Factors associated with advanced liver fibrosis in patients with non-alcoholic liver disease
}

\author{
Czynniki nasilonego włóknienia wątroby u osób z niealkoholową stłuszczeniową \\ chorobą wątroby
}

\author{
Joanna Raszeja-Wyszomirskaํ, Ewa Stachowska², Krzysztof Safranow³, Piotr Milkiewicz ${ }^{1}$ \\ 1Liver Unit, Pomeranian Medical University, Szczecin, Poland \\ 2Department of Biochemistry and Human Nutrition, Pomeranian Medical University, Szczecin, Poland \\ 3Department of Biochemistry, Pomeranian Medical University, Szczecin, Poland
}

Przegląd Gastroenterologiczny 2011; 6 (4): 234-242

DOI: 10.5114/pg.2011.24306

Key words: non-alcoholic fatty liver disease (NAFLD), serum aspartate aminotransferase/alanine aminotransferase (AST/ALT) ratio, hyaluronic acid, advanced fibrosis of the liver.

Słowa kluczowe: niealkoholowa stłuszczeniowa choroba wątroby (NAFLD), stosunek aminotransferazy asparaginianowej do alaninowej (AST/ALT) (AAR), kwas hialuronowy, zaawansowane włóknienie wątroby.

Address for correspondence: Joanna Raszeja-Wyszomirska MD, PhD, Liver Unit, Pomeranian Medical University, 72 Powstanców Wielkopolskich, 70-111 Szczecin, Poland, phone/fax: +48 9181394 35, e-mail: jorasz@sci.pam.szczecin.pl

\begin{abstract}
Introduction: Non-alcoholic fatty liver disease (NAFLD) is now the leading cause of chronic liver diseases in Western countries. It covers a spectrum of liver problems including benign simple steatosis (fatty liver) and steatohepatitis (NASH) with hepatic injury, inflammation, and fibrosis. Twenty percent of individuals with NASH progress to end-stage liver disease and cirrhosis. The mechanisms determining the progression from fatty liver to steatohepatitis are still unclear. The development and validation of accurate predictors would allow identification of patients at risk for advanced fibrosis, potentially helping monitor disease progression and response to therapeutic modalities.

Aim: To find biomarkers associated with more severe liver fibrosis in a cohort of Polish subjects with biopsy-proven NAFLD.

Results: Sixty consecutive Caucasian patients were enrolled in the study. Predictors of fibrosis F3 and F4 were older age, greater body mass index, higher serum total cholesterol, and increased aspartate aminotransferase/alanine aminotransferase (AST/ALT) ratio (AAR), as well as characteristics of insulin resistance and lower serum albumin levels. Increased serum levels of type IV collagen and hyaluronic acid were associated with more advanced liver disease. There were trends towards a relationship between advanced fibrosis and female gender, high serum triglycerides, and AST in univariate analysis.

Conclusions: Serum AAR and hyaluronic acid were independent factors associated with more advanced fibrosis in Polish patients with NAFLD in multivariate logistic regression analy-
\end{abstract}

\section{Streszczenie}

Wstęp: Niealkoholowa stłuszczeniowa choroba wątroby (nonalcoholic fatty liver disease - NAFLD) jest obecnie jednym z najczęściej rozpoznawanych przewlekłych schorzeń wątroby w świecie zachodnim. Obejmuje swym spektrum zarówno łagodne, proste stłuszczenie wątroby, jak i stłuszczeniowe zapalenie wątroby (non-alcoholic steatohepatitis - NASH) z jej stanem zapalnym i różnie nasilonym włóknieniem. U ok. 20\% chorych z NASH rozwinie się marskość wątroby ze schyłkową jej niewydolnością. Mechanizmy progresji prostego stłuszczenia wątroby do stłuszczeniowego zapalenia narządu nie są do końca poznane. Ich ustalenie pozwoliłoby na wczesną identyfikację chorych ze zwiększonym ryzykiem zaawansowanego włóknienia wątroby, monitorowanie progresji choroby oraz odpowiedź na postępowanie lecznicze.

Cel: Znalezienie biomarkerów nasilonego włóknienia wątroby w grupie polskich pacjentów z NAFLD potwierdzonym w badaniu biopsyjnym.

Wyniki: Do badania włączono 60 kolejnych chorych rasy kaukaskiej. Czynnikami związanymi z włóknieniem wątroby w stopniu F3 i F4 były: starszy wiek, większa masa ciała, większe stężenie cholesterolu całkowitego w surowicy oraz większy stosunek aminotransferazy asparaginianowej do alaninowej (AST/ALT), a także wyznaczniki insulinooporności i małe stężenie albumin w surowicy. Z bardziej zaawansowanym włóknieniem wątroby były ponadto związane większe stężenia kwasu hialuronowego i kolagenu typu IV w surowicy. Zaobserwowano ponadto korelację między płcią żeńską, większym stężeniem triglicerydów w surowicy oraz stężeniem AST a bardziej nasilonym włóknieniem wątroby w analizie jednoczynnikowej. 
sis. This population differs from previously described cohorts with fatty liver.
Wnioski: Kwas hialuronowy oraz zwiększony stosunek AST/ALT w surowicy były niezależnymi czynnikami zaawansowanego włóknienia wątroby $w$ wieloczynnikowej analizie regresji $\mathrm{w}$ populacji polskich pacjentów z potwierdzonym biopsyjnie rozpoznaniem NAFLD. Populacja ta pod kilkoma względami różni się od opisywanych dotychczas kohort z tym schorzeniem.

sue in the liver: liver biopsy with its disadvantages mentioned above, direct and indirect blood tests, and elastography [5]. Regrettably, both direct and indirect tests are not perfect for the diagnosis of liver fibrosis and their results varied among studied populations [6, 7]. An ideal non-invasive test for the assessment of hepatic fibrosis would be one that is sensitive, specific, free of additional cost to the patient, and applicable across all chronic liver diseases. Non-invasive tests for liver fibrosis have the potential to be important tools in clinical practice. It is likely that an initial diagnostic biopsy will still be needed, but follow-up for fibrosis could be based on non-invasive parameters. Research is needed to identify novel pathophysiological and therapeutic options in NAFLD, because it is a burgeoning health problem with a poorly understood natural history.

In this study we analysed some selected characteristics of Polish patients with NAFLD. We evaluated the role of serum biomarkers in NAFLD: hyaluronic acid (HA) a marker of perisinusoidal fibrosis and cirrhosis; type IV collagen - a component of the extracellular matrix; and cytokines implicated in the fibrogenetic process - transforming growth factor $\beta 1$ (TGF- $\beta 1$ ) and adiponectin - as potential predictors of severe fibrosis. We identified selected clinical parameters, distinctive for NAFLD patients from the north-western part of Poland.

\section{Material and methods}

Sixty consecutive Caucasian patients from the north-western part of Poland with biopsy-proven NAFLD were included in the study during 2006-2009. Some clinical (i.e. age, gender, history of arterial hypertension, hyperlipidaemia, diabetes mellitus type 2 - DMt2) and laboratory data as well as liver biopsy were collected during the same hospitalisation. The indication for the liver biopsy was elevation of $\operatorname{ALT} \geq 2 \times \mathrm{N}$. Only patients with a negative history of alcohol intake, i.e. those consuming less than $20 \mathrm{~g} /$ day, were included. All patients tested negative for HBV antigen and anti-HCV antibodies. Ceruloplasmin was checked and confirmed to be normal in patients aged 40 years or less. $\gamma$-Globulins, immunoglobulins, and auto-antibodies were analysed and imaging tests performed to exclude autoimmune hepatitis, primary biliary cirrhosis, and primary scleros-

ing cholangitis. Advanced fibrosis of the liver was infection with HCV-HIV [4]. There are three main tools used to quantify and monitor the amount of fibrotic tis- 
defined as bridging fibrosis and cirrhosis (F3 and F4) according to the Kleiner \& Brunt classification. Type IV collagen, TGF- $\beta 1$, hyaluronic acid, and adiponectin were measured in 54 patients by ELISA. Insulin resistance was calculated by the HOMA-IR formula (= fasting insulin value $\times$ fasting blood glucose/22.5)

\section{Statistical analysis}

Clinical and biochemical data were compared between groups of patients stratified according to fibrosis stage, as well as between males and females and diabetics/non-diabetics, with non-parametric MannWhitney test because distributions of most variables were significantly different from normal. Multivariate logistic regression adjusted for age and gender was used to find the independent predictors of advanced fibrosis among variables significantly associated with fibrosis in univariate analysis. Variables with a distribution different from normal (assessed with Shapiro-Wilk test) were transformed logarithmically before the multivariate analysis. Results with $p<0.05$ (without correction for multiple comparisons) were treated as statisti- cally significant. Statistica 7.1 software was used for the calculations.

\section{Results}

There were more males than females ( $65 \%$ vs. $35 \%$ ) in the analysed group. The median age of patients was 48 years (range 29-69 years in women, 25-75 years in men). Body mass index (BMI) in females ranged from $21.2 \mathrm{~kg} / \mathrm{m}^{2}$ to $39.3 \mathrm{~kg} / \mathrm{m}^{2}$ and in males from $24.0 \mathrm{~kg} / \mathrm{m}^{2}$ to $37.7 \mathrm{~kg} / \mathrm{m}^{2}$. More than half of the patients were obese (BMI > $30 \mathrm{~kg} / \mathrm{m}^{2}$ in $50.4 \%$ ) and $38.1 \%$ of patients were overweight $\left(25 \mathrm{~kg} / \mathrm{m}^{2}<\mathrm{BMI}<30 \mathrm{~kg} / \mathrm{m}^{2}\right)$.

Hypercholesterolaemia (total cholesterol $>200 \mathrm{mg} / \mathrm{dl}$ ) was present in $78.7 \%$ of patients; hypertriglyceridaemia (> $180 \mathrm{mg} / \mathrm{dl}$ ) in 29.5\%; type 2 diabetes mellitus (DMt2) in $18.6 \%$ (together with impaired fasting glucose [IFG] and impaired glucose tolerance [IGT], it was present in $24.56 \%$ of patients); and arterial hypertension in $21.7 \%$. The analysed biomarkers (TGF- $\beta 1$, adiponectin, type IV collagen, hyaluronic acid) were assessed in 54 participants. Data of patients are presented in Table I. Twelve patients (20\%, 7 females) had severe (F3-F4) fibrosis and

Table I. Selected clinical data in Polish patients with NAFLD. Biochemical parameters were measured in plasma or serum

Tabela I. Wybrane parametry kliniczne w badanej populacji. Parametry biochemiczne oceniano w osoczu lub surowicy

\begin{tabular}{|c|c|c|c|}
\hline Parameter & Median & Range & Mean \pm SD \\
\hline Age [years] & 48 & $25-75$ & $46.8 \pm 11.7$ \\
\hline BMI [19-25 kg/m²] & 29.2 & 21.2-39.3 & $29.3 \pm 4.1$ \\
\hline AST [<38 IU/I] & 46 & $16-275$ & $59.1 \pm 45.2$ \\
\hline $\operatorname{ALT}[<41 \mathrm{IU} / \mathrm{I}]$ & 75.5 & $15-281$ & $87.4 \pm 56.7$ \\
\hline AST/ALT ratio & 0.619 & $0.357-2.425$ & $0.79 \pm 0.47$ \\
\hline Albumin $[3.4-4.8 \mathrm{~g} / \mathrm{dl}]$ & 4.625 & $2.1-5.88$ & $4.5 \pm 0.58$ \\
\hline Platelets [150-400 × 109/I] & 218.5 & $93-376$ & $227.0 \pm 67.6$ \\
\hline Glucose $[<5.83 \mathrm{mmol} / \mathrm{l}]$ & 5.55 & $3.44-11.8$ & $5.67 \pm 1.33$ \\
\hline Insulin $[<187.5 \mathrm{pmol} / \mathrm{l}]$ & 109.6 & $13.89-1027.9$ & $186.1 \pm 227.8$ \\
\hline $\mathrm{HOMA}[>1.8]$ & 26.4 & $2.8-227.5$ & $34.7 \pm 35.4$ \\
\hline $\mathrm{Fe}[10.56-228.3 \mu \mathrm{mol} / \mathrm{l}]$ & 20.76 & $4.11-48.5$ & $20.74 \pm 8.36$ \\
\hline Ferritin [629.2-7999.3 pmol/l] & 563.9 & $62.9-12958.4$ & $1022.4 \pm 1793.3$ \\
\hline Transferrin saturation $[<45 \%]$ & 34.6 & 7.6-97.1 & $37.3 \pm 18.9$ \\
\hline Cholesterol $[<5.18 \mathrm{mg} / \mathrm{dl}]$ & 5.79 & $3.42-16.3$ & $5.97 \pm 1.73$ \\
\hline $\mathrm{HDL}[>1.04 \mathrm{mmol} / \mathrm{l}]$ & 1.35 & $0.31-3.49$ & $1.38 \pm 0.59$ \\
\hline $\mathrm{LDL}[<3.37 \mathrm{mmol} / \mathrm{l}]$ & 3.7 & $1.7-14.9$ & $3.86 \pm 1.78$ \\
\hline Triglycerides [< $12.03 \mathrm{mmol} / \mathrm{l}]$ & 1.49 & $0.64-5.79$ & $1.81 \pm 0.11$ \\
\hline TGF- $\beta 1[\mathrm{pg} / \mathrm{ml}]$ & 32996 & $8368-50556$ & $32827 \pm 8906$ \\
\hline Adiponectin [ng/ml] & 5367.5 & $1360-25000$ & $7434 \pm 5834$ \\
\hline Type IV collagen [ng/ml] & 126.65 & $67.8-1018.3$ & $195.5 \pm 191.4$ \\
\hline Hyaluronic acid [ng/ml] & 33.4 & $0-800$ & $81.15 \pm 137.6$ \\
\hline
\end{tabular}


Table II. Comparison of clinical and biochemical data between patients with no/mild (FO-F2) and advanced (F3-F4) fibrosis

Tabela II. Porównanie danych klinicznych i biochemicznych pomiędzy grupami pacjentów z włóknieniem watroby w stopniu FO-F2 (bez lub łagodne) i w stopniu F3-F4 (zaawansowane)

\begin{tabular}{|c|c|c|c|}
\hline Variable, mean \pm SD & Fibrosis FO-F2, $n=48$ & Fibrosis F3-F4, $n=12$ & Value of $p$ \\
\hline Age [years] & $45.9 \pm 11.9$ & $50.1 \pm 10.8$ & 0.23 \\
\hline BMI [19-25 kg/m²] & $28.9 \pm 3.75$ & $30.8 \pm 5.23$ & 0.35 \\
\hline $\mathrm{AST}[<38 \mathrm{IU} / \mathrm{I}]$ & $52.0 \pm 39.2$ & $87.0 \pm 57.1$ & 0.027 \\
\hline ALT $[<41 \mathrm{IU} / \mathrm{I}]$ & $89.5 \pm 52.4$ & $78.7 \pm 73.3$ & 0.20 \\
\hline AST/ALT ratio & $0.64 \pm 0.29$ & $1.38 \pm 0.55$ & 0.00000011 \\
\hline Albumin [3.4-4.8 g/l] & $4.68 \pm 0.40$ & $3.95 \pm 0.81$ & 0.0014 \\
\hline Platelets [150-400 × 109/I] & $229.1 \pm 67.9$ & $217.1 \pm 68.7$ & 0.75 \\
\hline Glucose $[<5.82 \mathrm{mmol} / \mathrm{l}]$ & $5.38 \pm 0.83$ & $7.158 \pm 2.24$ & 0.007 \\
\hline Insulin $[<187.5 \mathrm{pmol} / \mathrm{l}]$ & $164.6 \pm 236.1$ & $296.6 \pm 145.8$ & 0.00056 \\
\hline HOMA [> 1.8] & $39.7 \pm 36.8$ & $10.1 \pm 5.287$ & 0.000004 \\
\hline C-peptide $[\mathrm{nmol} / \mathrm{l}]$ & $1.34 \pm 0.82$ & $1.88 \pm 0.80$ & 0.027 \\
\hline Fe $[10.56-228.3 \mu \mathrm{mol} / \mathrm{ll}]$ & $20.3 \pm 7.50$ & $22.46 \pm 11.56$ & 0.71 \\
\hline Ferritin [629.2-7999.3 pmol/l] & $957.4 \pm 1982.5$ & $84.9 \pm 552.9$ & 0.31 \\
\hline Transferrin saturation $[<45 \%]$ & $36.2 \pm 18.3$ & $41.3 \pm 21.5$ & 0.38 \\
\hline Total cholesterol [< $5.18 \mathrm{mg} / \mathrm{dl}]$ & $5.66 \pm 1.09$ & $7.214 \pm 2.87$ & 0.022 \\
\hline $\mathrm{HDL}[>1.04 \mathrm{mmol} / \mathrm{l}]$ & $1.38 \pm 0.51$ & $1.39 \pm 0.88$ & 0.56 \\
\hline $\operatorname{LDL}[<3.37 \mathrm{mmol} / \mathrm{l}]$ & $3.61 \pm 0.96$ & $4.74 \pm 0.20$ & 0.16 \\
\hline Triglycerides [< $12.03 \mathrm{mmol} / \mathrm{l}]$ & $1.81 \pm 1.10$ & $1.79 \pm 0.66$ & 0.45 \\
\hline TGF- $\beta 1[\mathrm{pg} / \mathrm{ml}]$ & $32645 \pm 9313$ & $33629 \pm 7200$ & 0.75 \\
\hline Adiponectin [ng/ml] & $7547.0 \pm 6099.5$ & $6935.4 \pm 4727.6$ & 0.97 \\
\hline Type IV collagen [ng/ml] & $146.6 \pm 118.9$ & $410.5 \pm 291.5$ & 0.00000113 \\
\hline Hyaluronic acid [ng/ml] & $42.9 \pm 65.4$ & $248.6 \pm 229.7$ & 0.00000131 \\
\hline
\end{tabular}

24 (40\%) no fibrosis (F0). Table II summarizes data in relationship to the stage of fibrosis.

In univariate analysis higher total serum cholesterol, insulin, glycaemia, C-peptide, higher aspartate aminotransferase (AST) and aspartate aminotransferase/alanine aminotransferase (AST/ALT) ratio (AAR), and lower albumin levels were associated with more severe fibrosis, defined as bridging fibrosis and cirrhosis of the liver (Table II). There were more females in the F3-F4 subgroup and there was a trend towards a relationship between female gender and more severe fibrosis (Fisher exact test, $p=0.08$ ). Data comparing males and females included in the study are summarized in Table III. We found older age; lower ALT, HOMA, iron, transferrin saturation and albumin levels; higher AAR, insulin, C-peptide, total cholesterol and its LDL fraction; and higher levels of adiponectin and hyaluronic acid in females than in males. Patients with DMt2 were older and had higher glucose, HOMA and glycated haemoglobin levels, as well as AST, AARs, and iron. They also had higher type IV collagen and hyaluronic acid. These data are shown in Table IV.

The multivariate logistic regression analysis, adjusted for age and gender (Table V), determined higher serum AAR and hyaluronic acid to be independent risk factors of more advanced fibrosis. Collagen IV strongly correlated with hyaluronic acid; thus, it was not an independent risk factor. The multivariate model showed no association of fibrosis with serum albumin and total cholesterol.

\section{Discussion}

The natural history of NAFLD remains poorly understood and the search for non-invasive methods to identify patients at greatest risk for progression to advanced fibrosis and cirrhosis remains elusive. Several demographic, anthropomorphic, clinical, and laboratory features are associated with NAFLD and with the histological severity of the disease. Some useful predictors of NAFLD progression include race (Hispanic), older age 
Table III. Main clinical differences between Polish NAFLD males and females. Values of $p$ refer to a univariate analysis

Tabela III. Główne różnice kliniczne między mężczyznami i kobietami z NAFLD w badanej populacji. Wartości $p$ odniesiono do analizy jednoczynnikowej

\begin{tabular}{|c|c|c|c|}
\hline Variable & Females (mean $\pm \mathrm{SD}$ ), $n=21$ & Males (mean $\pm \mathrm{SD}$ ), $n=39$ & Value of $p$ \\
\hline Age [years] & $51.8 \pm 11.4$ & $44.1 \pm 11.0$ & 0.01 \\
\hline BMI [19-25 kg/m²] & $30.1 \pm 4.7$ & $28.8 \pm 3.71$ & 0.25 \\
\hline AST $[<38 \mathrm{IU} / \mathrm{II}]$ & $61.7 \pm 46.2$ & $57.8 \pm 45.2$ & 0.880 \\
\hline $\operatorname{ALT}[<41 \mathrm{IU} / \mathrm{I}]$ & $65.3 \pm 42.5$ & $99.2 \pm 60.2$ & 0.023 \\
\hline AST/ALT ratio & $1.14 \pm 0.6$ & $0.61 \pm 0.24$ & 0.00012 \\
\hline Albumin $[3.4-4.8 \mathrm{~g} / \mathrm{dl}]$ & $4.28 \pm 0.6$ & $4.67 \pm 0.5$ & 0.003 \\
\hline Platelets [150-400 × 109/I] & $218.1 \pm 62.7$ & $231.7 \pm 70.3$ & 0.542 \\
\hline Glucose $[<5.82 \mathrm{mmol} / \mathrm{l}]$ & $5.83 \pm 1.93$ & $5.59 \pm 0.92$ & 0.85 \\
\hline Insulin [<187.5 pmol/l] & $249.3 \pm 225.7$ & $152.1 \pm 225.7$ & 0.005 \\
\hline HOMA [> 1.8] & $23.36 \pm 23.2$ & $40.5 \pm 39.3$ & 0.018 \\
\hline $\mathrm{Fe}[10.56-228.3 \mu \mathrm{mol} / \mathrm{l}]$ & $17.23 \pm 6.92$ & $22.62 \pm 8.53$ & 0.025 \\
\hline Ferritin [629.2-7999.3 pmol/l] & $549.2 \pm 395.2$ & $1136.9 \pm 2183.2$ & 0.14 \\
\hline Transferrin saturation $(<45 \%)$ & $29.2 \pm 11.9$ & $41.6 \pm 20.5$ & 0.016 \\
\hline Total cholesterol [<5.18 mg/dl] & $6.34 \pm 0.97$ & $5.72 \pm 2.00$ & 0.01 \\
\hline $\mathrm{HDL}[>1.04 \mathrm{mmol} / \mathrm{l}]$ & $1.54 \pm 0.7$ & $2.19 \pm 0.52$ & 0.101 \\
\hline $\mathrm{LDL}[<3.37 \mathrm{mmol} / \mathrm{l}]$ & $4.05 \pm 0.96$ & $3.76 \pm 2.01$ & 0.049 \\
\hline Triglycerides [< $12.03 \mathrm{mmol} / \mathrm{l}]$ & $4.53 \pm 2.72$ & $3.94 \pm 2.14$ & 0.432 \\
\hline TGF- $\beta 1[\mathrm{pg} / \mathrm{ml}] n=19 / n=35$ & $30990.95 \pm 10370.09$ & $33824.06 \pm 7987.9$ & 0.35 \\
\hline Adiponectin [ng/ml] & $10262.8 \pm 7286.7$ & $5897.9 \pm 4248.2$ & 0.012 \\
\hline Hyaluronic acid [ng/ml] & $142.3 \pm 198.9$ & $47.8 \pm 72.9$ & 0.027 \\
\hline Collagen type IV [ng/ml] & $293.1 \pm 289.7$ & $142.5 \pm 66.7$ & 0.079 \\
\hline
\end{tabular}

(> 50 years of age), DMt2 and other markers of insulin resistance (insulin, C-peptide, HOMA, QUICKI), arterial hypertension, and central obesity [8].

The population of patients from the north-western part of Poland with NAFLD analysed in this study is similar to previously described cohorts, in respect to demographic and clinical data $[9,10]$, although there are some differences. The male predominance in our cohort is the opposite of Harrison et al.'s [9] study but similar to the study by Angulo et al. [10] with mostly Caucasians. Although NASH was initially described as a disease predominantly affecting women [11], there are still controversies on this matter. Recently, we evaluated the HFE gene mutation in Caucasians with NAFLD, and multivariate logistic regression analysis showed female gender as a risk factor for more advanced fibrosis [12]. Also, in the present study, females were predominant in the F3-F4 subgroup, showing a trend by the Fisher test $(p=0.08)$. In Harrison et al.'s study, women were overrepresented in the cohort of patients with NASH and advanced fibrosis; this was not confirmed in other stud- ies and it has been suggested that there are no gender differences $[8,13,14]$. Further studies are required evaluating gender and, perhaps, ethnicity.

Our NAFLD population is less obese than patients described in the largest cohort studies. The median BMI in this study was less than $30 \mathrm{~kg} / \mathrm{m}^{2}$ compared to $33 \mathrm{~kg} / \mathrm{m}^{2}$ in Harrison's work [9], and no patient presented with a BMI $>40 \mathrm{~kg} / \mathrm{m}^{2}$ (16\% of patients in Harrison's group were classified as morbidly obese). Moreover, $10 \%$ of individuals had normal BMI in our cohort, compared to $3 \%$ in Harrison's group [9]. Although greater $\mathrm{BMI}$ is usually connected with prolonged obesity, the distribution of fat seems to be more important in fatty liver. Non-alcoholic fatty liver disease, in the presence of normoglycaemia and normal or moderately increased body weight, is characterized by clinical and laboratory data similar to those found in diabetes and obesity, as shown by Marchesini et al. [15].

The third difference in our study, compared to the American studies, is the most common co-morbidities, including the components of metabolic syndrome. Only $18.64 \%$ of our patients suffered from DMt2. In studies 
Table IV. Selected data in subgroup of NAFLD patients with and without DMt2. Values of $p$ refer to a univariate analysis

Tabela IV. Wybrane parametry w grupie osób z NAFLD oraz z cukrzyca typu 2 lub bez niej. Wartości p odniesiono do analizy jednoczynnikowej

\begin{tabular}{|c|c|c|c|}
\hline Variable & Non-diabetics, $n=48($ mean $\pm S D)$ & Diabetics, $n=11$ (mean \pm SD) & Value of $p$ \\
\hline Age [years] & $45.5 \pm 12.3$ & $52.3 \pm 7.5$ & 0.043 \\
\hline BMI $\left[19-25 \mathrm{~kg} / \mathrm{m}^{2}\right]$ & $28.9 \pm 4.07$ & $30.9 \pm 4.2$ & 0.13 \\
\hline AST [<38 IU/I] & $52.64 \pm 36.7$ & $85.9 \pm 68.1$ & 0.021 \\
\hline $\operatorname{ALT}[<41 \mathrm{IU} / \mathrm{l}]$ & $83 \pm 52.4$ & $100.6 \pm 73.4$ & 0.50 \\
\hline AST/ALT ratio & $0.75 \pm 0.43$ & $1.02 \pm 0.57$ & 0.046 \\
\hline Albumin $[3.4-4.8 \mathrm{~g} / \mathrm{dl}]$ & $4.57 \pm 0.57$ & $4.32 \pm 0.61$ & 0.08 \\
\hline Platelets [150-400 × 109/1] & $226.2 \pm 63.6$ & $228.6 \pm 90.3$ & 0.92 \\
\hline Glucose $[<5.82 \mathrm{mmol} / \mathrm{l}]$ & $5.32 \pm 0.78$ & $7.25 \pm 2.03$ & 0.000159 \\
\hline Glycated haemoglobin [4.8-5.9\%] & $5.71 \pm 0.48$ & $7.92 \pm 1.75$ & 0.0006 \\
\hline Insulin $[<187.5 \mathrm{pmol} / \mathrm{l}]$ & $177.7 \pm 244.5$ & $229.8 \pm 168.7$ & 0.091 \\
\hline C-peptide $[\mathrm{nmol} / \mathrm{l}]$ & $1.36 \pm 0.83$ & $0.77 \pm 0.83$ & 0.10 \\
\hline $\mathrm{HOMA}[>1.8]$ & $38.65 \pm 38.34$ & $19.3 \pm 18.4$ & 0.04 \\
\hline $\mathrm{Fe}[10.56-228.3 \mu \mathrm{mol} / \mathrm{l}]$ & $19.53 \pm 7.5$ & $25.7 \pm 10.6$ & 0.036 \\
\hline Ferritin [629.2-7999.3 pmol/l] & $948.0 \pm 1953.5$ & $905.3 \pm 961.3$ & 0.79 \\
\hline Transferrin saturation [< 45\%] & $35.45 \pm 18.2$ & $44.27 \pm 21.8$ & 0.078 \\
\hline Total cholesterol [<5.18 mg/dl] & $5.93 \pm 1.87$ & $6.17 \pm 1.07$ & 0.31 \\
\hline $\mathrm{HDL}[>1.04 \mathrm{mmol} / \mathrm{l}]$ & $1.36 \pm 0.57$ & $1.53 \pm 0.7$ & 0.55 \\
\hline $\mathrm{LDL}[<3.37 \mathrm{mmol} / \mathrm{l}]$ & $3.86 \pm 1.99$ & $3.83 \pm 0.59$ & 0.48 \\
\hline Triglycerides [< $12.03 \mathrm{mmol} / \mathrm{l}]$ & $1.82 \pm 1.1$ & $1.77 \pm 0.67$ & 0.34 \\
\hline TGF- $\beta 1[p g / m l], n=45 / n=9$ & $32705.2 \pm 9370.0$ & $33437.3 \pm 6489.3$ & 0.66 \\
\hline Adiponectin [ng/ml] & $7806.8 \pm 6305.2$ & $5568.6 \pm 1464.0$ & 0.78 \\
\hline Collagen type IV [ng/ml] & $164.6 \pm 163.8$ & $349.9 \pm 250.7$ & 0.003 \\
\hline Hyaluronic acid [ng/ml] & $56.6 \pm 122.8$ & $203.3 \pm 149.3$ & 0.004 \\
\hline
\end{tabular}

by Harrison and Angulo et al., DMt2 affected 35\% and $30 \%$ of individuals, respectively. All these studies favour routine oral glucose tolerance tests for the assessment of patients with NAFLD [16]. Diabetes plays an important role in the development and progression of fibrosis within NAFLD; the results of our study - showing clearly higher glucose, insulin, C-peptide and HOMA levels in the F3-F4 subgroup - also support the findings of Younossi et al. [17], and make a case for active screening for DMt2.

The population of NAFLD patients from the northwestern part of Poland suffering from DMt2 was older than other participants, and had higher serum iron, glycaemia, glycated haemoglobin levels and lower HOMA. AST as well as AARs were higher in this subgroup. Of note, type IV of the collagen and hyaluronic acid were higher in diabetics compared to the rest of the analysed NAFLD population. These findings support an association between DMt2 and NAFLD.
Hyperlipidaemia was present in $42 \%$ of Harrison et al.'s USA population. Results from this study showed that hypercholesterolaemia was present in $78.7 \%$ and hypertriglyceridaemia in $29.5 \%$ of subjects. In Angulo et al.'s study - the biggest multi-centre study, of 733 predominantly Caucasian patients - hypertriglyceridaemia was present in $60 \%$ of subjects. Although dyslipidaemia is a common finding in NAFLD patients, it was not associated with greater risk of advanced fibrosis in studies by Angulo et al. and Harrison et al. Hypertriglyceridaemia is strongly associated with NAFLD, but the association with cholesterol has not yet been convincingly demonstrated [1]. In the current study, we observed differences in total cholesterol plasma levels between NAFLD patients with less and more severe fibrosis. The median level of cholesterol in the F0-F2 subgroup was $214 \mathrm{mg} / \mathrm{dl}$ vs. $246 \mathrm{mg} / \mathrm{dl}$ in the F3-F4 population $(p<0.016)$. There were no correlations between levels of LDL and HDL cholesterol and fibrosis severity, although 
Table V. Multivariate logistic regression model predicting presence of advanced fibrosis (F3-F4) in NAFLD patients

Tabela V. Model wieloczynnikowej regresji logistycznej przewidujący występowanie zaawansowanego włóknienia wątroby w grupie osób z NAFLD

\begin{tabular}{lcc} 
Parameter & OR $(95 \% \mathrm{Cl})$ & Value of $p$ \\
\hline Age [years] & $0.90(0.78-1.04)$ & 0.16 \\
\hline Male gender & $1.94(0.11-35.58)$ & 0.65 \\
\hline Hyaluronic acid* $^{*}$ & $4.84(1.12-20.85)$ & 0.030 \\
\hline AST/ALT ratio* $^{*}$ & $60.36(2.23-1630)$ & 0.012
\end{tabular}

*The variable was transformed logarithmically - odds ratio (OR) relates to the predicted increase of odds for advanced fibrosis associated with 10-fold increase of the parameter values, $95 \% \mathrm{Cl}$ - $95 \%$ confidence interval

we found higher levels of LDL among NAFLD patients with F3-F4 fibrosis. HDL cholesterol had no such correlation. The explanation for this phenomenon is complex. As we know, hydroxymethylglutaryl-CoA (HMG-CoA) is a key enzyme in cholesterol synthesis. HMG-CoA is transcriptionally controlled by sterol regulatory elementbinding protein-2 (SREBP-2). Caballero et al. found that SREBP-2 mRNA levels were 3- to 4-fold higher in NAFLD [18] subjects, and concluded that free cholesterol levels increased during NASH and correlated with the induction of SREPB-2. Our results may support a novel link between serum cholesterol and liver fibrosis progression in NAFLD. Cholesterol may be a player in disease progression and a novel target for intervention [18].

A nutritional approach provided helpful information in understanding the nature of NAFLD; superabundant dietary cholesterol and decreased dietary polyunsaturated fatty acid intake may contribute to NAFLD development [19]. The connection between food-derived cholesterol and liver fibrosis is provided by Acyl-CoA: cholesterol acyltransferase (ACAT) activity, which promotes cholesterol absorption and secretion of very-lowdensity lipoprotein by the liver. Mice genetically lacking ACAT2 were protected against hepatic neutral lipid accumulation [20]. The highest cholesterol levels were observed in the F3-F4 subgroup of our NAFLD patients and ACAT2 activation might be a hypothesis for the explanation of the current results. Most importantly in our study, only total cholesterol, not LDL and HDL cholesterol, seemed to be of importance. Thus, the hypothesis can be stated that inhibition of cholesterol intake from the gut decreased blood cholesterol concentration and suppressed hepatic injury in non-obese patients with NAFLD [21]. Unfortunately, these results come from univariate analysis, not corrected for multiple compari- son, so are not significant, and are additionally underpowered, with too few patients in the severe fibrosis group. However, it seems that further studies are needed, because of the number of individuals with NAFLD and hypercholesterolaemia.

In the current study we noted higher levels of adiponectin, higher total cholesterol as well as its LDL fraction, and lower serum iron and transferrin saturation in NAFLD females from the north-western part of Poland. Adiponectin functions to decrease gluconeogenesis and to increase glucose uptake, lipid $\beta$-oxidation and triglyceride clearance, protection from endothelial dysfunction, insulin sensitivity, and control of energy metabolism. It is also an anti-inflammatory adipokine, preventing the accumulation of lipids in hepatocytes and enhancing their sensitivity to insulin. Its lower serum level is associated with more severe fibrosis in NAFLD [22]. Although females differed from males in the analysed cohort with respect to weight and height, the adiponectin levels were higher in females due to wellknown differences in body composition between genders; thus our finding supports previous results [23].

Serum ferritin, reflecting the tissue pool of iron, is often raised in NAFLD patients [24, 25] and has been associated with advanced liver fibrosis [26] and increased vascular damage in NAFLD [27]. In a Polish cohort, we recently found the highest serum ferritin levels in a subgroup of NASH patients with F3-F4 fibrosis; however, it was without statistical significance and higher levels of serum iron, as well as DMt2, were associated with severe liver fibrosis [12]. There is growing evidence that iron and glucose metabolism are interdependent and that increased iron stores may contribute to insulin resistance (IR). On the other hand, the interaction between NAFLD and hyperinsulinaemia is the major determinant of serum ferritin levels [28]. Valenti et al. [29] showed that higher iron stores were associated with more advanced liver fibrosis. Higher total cholesterol with increased iron (both in plasma and tissues) may lead to excessive free fatty acid oxidation with free oxygen radical formation, increased inflammation, and fibrogenesis in NAFLD.

The multivariate logistic regression analysis showed that AAR and hyaluronic acid were independent risk factors for more advanced fibrosis in our patients. High AAR has been related to reduced sinusoidal clearance of AST relative to ALT [30], and seems to be a better predictor of advanced liver disease than ALT alone [31]. Although increased AST and ALT levels are considered markers of necrotic cell death, this may result from necrosis secondary to apoptosis [32]. On the other hand, central obesity, raised triglycerides, reduced HDL cholesterol, and raised fasting glucose may contribute to 
increased ALT activity [33]; elevated ALT is connected with metabolic syndrome, cardiovascular disease, and DMt2 [34]. Elevated aminotransferase levels were independent predictors of moderate-to-severe fibrosis [35], and NAFLD with elevated liver enzymes was associated with a clinically significant risk of developing end-stage liver disease [36]; yet, only the papers by Harrison et al. and Angulo et al. pointed out the usefulness of AAR in detecting NAFLD individuals with more advanced fibrosis. The results from this study confirmed that AAR is an independent risk factor of more severe fibrosis in NAFLD.

Direct analysis of qualitative and quantitative changes in the extracellular matrix of the liver included markers connected to matrix degradation or its accumulation. Type IV collagen and hyaluronic acid are associated with more severe fibrosis as well as profibrotic TGF- $\beta 1$. Acute and chronic liver injury results in increased local and systemic concentrations of TGF- $\beta 1$, a cytokine that causes apoptosis via increased cellular oxidative stress and subsequent caspase activation [37]. Increased expression of plasma TGF- $\beta 1$, which activates Kupffer and stellate cells, is described in individuals with NAFLD [8]. The results of our study showed no correlation between serum levels of this potent fibrogenic cytokine and liver damage. In the current study, we did not observe significant differences even in the subgroup of NAFLD and DMt2 patients, prone to more severe fibrosis of the liver. However, the induction of TGF- $\beta 1$ must occur first, before the activation of stellate cells, either from autocrine or paracrine sources; it is possible that stimulation of collagen transcription in stellate cells via Smads, as well as connective tissue growth factor stimulation, is also TGF- $\beta 1$-independent [38].

In our study, type IV collagen and hyaluronic acid were associated with more severe fibrosis (F3-F4). Hyaluronic acid, laminin, and collagen are extracellular matrix components; hyaluronic acid may increase in fibrosis due to a mixture of increased collagen turnover and reduced hepatic clearance. Our results support the outcomes from previous studies [39] and the role of extracellular matrix in the progression of fibrosis. Type IV collagen was not an independent risk factor of severe fibrosis in these NAFLD patients; however, its plasma amount was significantly higher in diabetics, suggesting glycation processes of proteoglycans. Only one study showed the value of this protein in NAFLD [40]. It is important to remember that there is no specific type of collagen or extracellular matrix components in the liver [5]. Hyaluronic acid, as a single biomarker, fulfilled the criteria for a good predictor of fibrosis; it is inexpensive, obtained from blood, and also useful in subjects of different race and indications [41].

\section{Conclusions}

Our study showed an association of clinical and laboratory data with stage of NAFLD severity. Serum AAR and hyaluronic acid were independent factors associated with more advanced fibrosis in patients with NAFLD from the north-western part of Poland. This cohort differs from previously described populations with fatty liver.

\section{Acknowledgments}

This paper was supported by a grant from the State Committee for Scientific Research, in years 2006-2009, No. N 402099 31/3037. All the authors declare no conflict of interest.

\section{References}

1. de Alvis NMW, Day CP. Non-alcoholic fatty liver disease: the mist gradually clears. J Hepatol 2008; 48: S104-112.

2. Cusi K. Role of insulin resistance and lipotoxicity in non-alcoholic steatohepatitis. Clin Liver Dis 2009; 13: 545-63.

3. Argo CK, Northup PG, Al-Osaimi AMS, et al. Systematic review of risk factors for fibrosis progression in non-alcoholic steatohepatitis. J Hepatol 2009; 51: 371-9.

4. Pinzani M, Rombouts K, Colagrande S. Fibrosis in chronic liver diseases: diagnosis and management. J Hepatol 2005; 42: S22-36.

5. Beaugrand M. How to assess liver fibrosis and for what purpose? J Hepatol 2006; 44: 444-5.

6. Burroughs AK, Cholongitas E. Non-invasive tests for liver fibrosis: encouraging or discouraging results? J Hepatol 2007; 46: 751-5.

7. Shah A, Lydecker A, Murray K, et al.; NASH Clinical Research Network. Comparison of noninvasive markers of fibrosis in patients with nonalcoholic fatty liver disease. Clin Gastroenterol Hepatol 2009; 7: 1104-12.

8. Pagadala M, Zein CO, McCullough AJ. Predictors of steatohepatitis and advanced fibrosis in non-alcoholic fatty liver disease. Clin Liver Dis 2009; 13: 591-606.

9. Harrison SA, Oliver D, Arnold HL, et al. Development and validation of a simple NAFLD clinical scoring system for identifying patients without advanced disease. Gut 2008; 57: 1441-7.

10. Angulo P, Hui JM, Marchesini G, et al. The NAFLD Fibrosis Score: a noninvasive system that identifies liver fibrosis in patients with NAFLD. Hepatology 2007; 45: 846-54.

11. Lee RG. Nonalcoholic steatohepatitis: a study of 49 patients. Hum Pathol 1989; 20: 594-8.

12. Raszeja-Wyszomirska J, Kurzawski G, Lawniczak M, et al. Nonalcoholic fatty liver disease and HFE gene mutations: the Polish study. World J Gastroenterol 2010; 16: 2531-6.

13. Angulo P, Alba LM, Petrovic LM. Leptin, insulin resistance, and liver fibrosis in human nonalcoholic fatty liver disease. J Hepatol 2004; 41: 943-9.

14. Raszeja-Wyszomirska J, Szymanik B, Ławniczak M, et al. Validation of the BARD scoring system in Polish patients with nonalcoholic fatty liver disease (NAFLD). BMC Gastroenterology 2010; 67: 1-6. 
15. Marchesini G, Brizi M, Bianchi G, et al. Nonalcoholic fatty liver disease: a feature of the metabolic syndrome. Diabetes 2001; 50: 1844-50.

16. Haukeland JW, Konopski Z, Linnestad P, et al. Abnormal glucose tolerance is a predictor of steatohepatitis and fibrosis in patients with non-alcoholic fatty liver disease. Scand J Gastroenterol 2005; 40: 1469-77.

17. Younossi ZM, Gramlich T, Matteoni CA, et al. Non-alcoholic fatty liver disease in patients with type 2 diabetes. Clin Gastroenterol Hepatol 2004; 2: 262-5.

18. Caballero F, Fernández A, De Lacy AM, et al. Enhanced free cholesterol, SREBP-2 and StAR expression in human NASH. J Hepatol 2009; 50: 789-96.

19. Yasutake K, Nakamuta M, Shima Y, et al. Nutritional investigation of non-obese patients with non-alcoholic fatty liver disease: the significance of dietary cholesterol. Scand J Gastroenterol 2009; 44: 471-7.

20. Alger HM, Brown JM, Sawyer JK, et al. Inhibition of acyl-coenzyme a: cholesterol acyltransferase 2 (ACAT2) prevents dietary cholesterol associated steatosis by enhancing hepatic triglyceride mobilization. J Biol Chem 2010; 285: 14267-74.

21. Enjoji M, Machida K, Kohjima M, et al. NPC1L1 inhibitor ezetimibe is a reliable therapeutic agent for non-obese patients with nonalcoholic fatty liver disease. Lipids Health Dis 2010; 9: 29.

22. Yamauchi T, Kamon J, Ito Y, et al. Cloning of adiponectin receptors that mediate antidiabetic metabolic effects. Nature 2003; 423: 762-9.

23. Coppola A, Marfella R, Coppola L, et al. Effect of weight loss on coronary circulation and adiponectin levels in obese women. Int J Cardiol 2008; 134: 414-6.

24. Bugianesi E, Manzini P, D’Antico S, et al. Relative contribution of iron burden, HFE mutations, and insulin resistance to fibrosis in non-alcoholic fatty liver. Hepatology 2004; 39: 179-87.

25. Trombini P, Piperno A. Ferritin, metabolic syndrome and NAFLD: elective attractions and dangerous liaisons. J Hepatol 2007; 46: 549-52.

26. Pankow JS, Boerwinkle E, Adams PC, et al. HFE C282Y homozygotes have reduced low-density lipoprotein cholesterol: the Atherosclerosis Risk in Communities (ARIC) study. Tranl Res 2008; 152: 3-10.

27. Valenti L, Swinkels DW, Burdick L, et al. Serum ferritin levels are associated with vascular damage in patients with nonalcoholic fatty liver disease. Nutr Metabol Cardiovasc Dis 2011; 21: 568-75.

28. Zelber-Sagi S, Nitzan-Kaluski D, Halpern Z, et al. NAFLD and hyperinsulinemia are major determinants of serum ferritin levels. J Hepatol 2007; 46: 700-7.

29. Valenti L, Dongiovanni P, Piperno A, et al. Alpha1-antitrypsin mutations in NAFLD: high prevalence and association with altered iron metabolism but not with liver damage. Hepatology 2006; 44: 857-64.

30. Guha IN, Parkes J, Roderick P, et al. Noninvasive markers of fibrosis in nonalcoholic fatty liver disease: validating the European Liver Fibrosis Panel and exploring simple markers. Hepatology 2008; 47: 455-60.

31. Fracanzani AL, Valenti L, Bugianesi E, et al. Risk of severe level disease in nonalcoholic fatty liver disease with normal aminotransferase levels: a role for insulin resistance and diabetes. Hepatology 2008; 48: 792-8.
32. Moshage $\mathrm{H}$. The cirrhotic hepatocytes: navigating between Scylla and Charybdis. J Hepatol 2004; 40: 1027-9.

33. Oh SY, Cho YK, Kang MS, et al. The association between increased alanine aminotransferase activity and metabolic factros in nonalcoholic fatty liver disease. Metabolism 2006; 55: 1604-9.

34. Bethel MA, Deedwania P, Levitt NS, et al. For the NAVIGATOR Study Group Metabolic syndrome and alanine aminotransferase: a global perspective from the NAVIGATOR screening population. Diabet Med 2009; 26: 1204-11.

35. Hossain N, Afendy A, Stepanova M, et al. Independent predictors of fibrosis in patients with nonalcoholic fatty liver disease. Clin Gastroenterol Hepatol 2009; 7: 1224-9.

36. Ekstedt M, Franzen LE, Mathiesen UL, et al. Long-term followup of patients with NAFLD and elevated liver enzymes. Hepatology 2006; 44: 865-73.

37. Black D, Bird MA, Samson CM, et al. Primary cirrhotic hepatocytes resist TGFbeta-induced apoptosis through a ROS-dependent mechanism. J Hepatol 2004; 40: 942-51.

38. Friedman SL. Mechanism of hepatic fibrogenesis. Gastroenterology 2008; 134: 1655-69.

39. Suzuki A, Angulo P, Lymp J, et al. Hyaluronic acid, an accurate serum marker for severe hepatic fibrosis in patients with nonalcoholic fatty liver disease. Liver Int 2005; 25: 779-86.

40. Santos VN, Leite-Mor MM, Kondo M, et al. Serum laminin, type IV collagen and hyaluronan as fibrosis markers in nonalcoholic fatty liver disease. Braz J Med Biol Res 2005; 38 : 747-53.

41. Esmat G, Metwally M, Zalata KR, et al. Evaluation of serum biomarkers of fibrosis and injury in Egyptian patients with chronic hepatitis C. J Hepatol 2007; i46: 620-7. 